\title{
Sialyl-Tn Antigen Antibody
}

National Cancer Institute

\section{Source}

National Cancer Institute. Sialyl-Tn Antigen Antibody. NCI Thesaurus. Code C120488.

Any immunog lobulin that recognizes the sialylated form of the Tn antigen. 